\title{
Investigating green supply chain practices for economic growth
}

\author{
Bakhtiar Abbas $^{\mathrm{a}^{*}}$, Abdul Razak ${ }^{\mathrm{b}}$ and Ismail Suardi Wekke
}

${ }^{a}$ Sekolah Tinggi Ilmu Ekonomi Enam Enam, Kendari, Indonesia ${ }^{b}$ Sekolah Tinggi Agama Islam Negeri (STAIN) Sorong, Indonesia

\begin{tabular}{l}
\hline C H R O N I C L E \\
\hline Article history: \\
Received November 4, 2018 \\
Received in revised format \\
December 20, 2018 \\
Accepted January 62019 \\
Available online \\
January 62019 \\
\hline Keywords: \\
Foreign direct investment \\
(FDI) \\
Green supply chain (GSC) \\
Exports \\
Economic growth
\end{tabular}

\section{A B S T R A C T}

Indonesia has recorded tremendous growth in this decade given a new dimension to her economy. Presently Indonesian economy is the fourth largest in East Asia, after China, South Korea and Japan - and one of the largest in terms of purchasing power parity (PPP), worldwide. This performance can be further improved by employing better supply chain practices. This study observes how green supply chain (GSC) practices can improve foreign direct investment (FDI) and export on Indonesian economic growth. Data is collected from Indonesian economists through a survey questionnaire and is analyzed using PLS-SEM. The results of the study indicate that GSC had positive impact on the economic growth of Indonesia. GSC has also maintained a positive impact on exports and FDI and it is considered crucial for the economic growth. The study shall have broad implications in strategic formulations to boost economic growth.

\section{Introduction}

Logistics management is a critical segment of supply chain. Effective logistics management enhances the storage of inventory, material management, transportation as well as data handling needed to transfer items on a supply chain platform (Martel \& Klibi, 2016). During the years of 90s, the idea of green supply chain (GSC) was first acknowledged by a few logisticians and confirmed that logistics was a huge cause of pollution, and eventually influences a nation's economic growth. Khan et al. (2017) examined the connection between GSC and economic aspects and demonstrated that assembling, per capita income, and gross domestic product are extraordinarily influenced by carbon emissions from logistic transport.

Since the outbreak of industrial revolution, numerous organizations have utilized global sourcing. Owing to globalization, several developing nations for ensuring economic growth have adopted global sourcing as a competitive advantage. On the contrary, global sourcing truly influences the environment; because of the tremendous inclusion of transportation (Khan et al., 2016). In this comparison, United Nation (2014) represented some huge realities concerning transportation. For instance, transportation was responsible for approximately $22 \%$ of the overall carbon dioxide emissions $\left(\mathrm{CO}_{2}\right)$ and for almost

\footnotetext{
* Corresponding author
}

E-mail address: babbas@stie-66.ac.id (B. Abbas) 
$19 \%$ of dark carbon that negatively affects the environment, people's lives and causes diseases. Hutchins and Sutherland (2008) stressed the need for social sustainability of companies under the premises of the green supply chain framework.

Several organizations have adopted a GSC as an environment friendly practice which not only increased their performance but also positively affected the economic growth of a country. The adoption of GSC practices and initiating a cleaner advancement have improved the environmental maintainability as well as increased the organizations' performance enabling them to attain a competitive advantage (Rao \& Holt, 2005). The new concept of greenhouse gas has a significant influence also on the environment (Demir et al., 2014; Khan et al., 2016). The novel concept of green paths has fundamentally decreased the $\mathrm{CO}_{2}$ emissions which has enhanced the environmental performance of products and service transportation. Report of European Commission may be cited which informs that although approximately 10 million people are employed in various transportation industries, but total business yield is accounted for only $4.6 \%$ in gross domestic product. The transportation companies use $96 \%$ of their energy requirements from oil products. Along these lines, their promise to greenhouse gas emanations is around 35\% amid 1990-2008 (EUROPA, 2011). Such GSC effect on environmental has a significant link with the economic growth particularly the emerging economies such as Indonesia, Malaysia, India, Pakistan, etc.

In the case of Indonesia, economy is growing rapidly. Fig. 1 shows the economic growth of Indonesia from 1980 to 2016. The Indonesian economy has recorded a solid gradual growth in the recent decades which has proved a vital element of the global economy. Presently Indonesian economy is the fourth largest economy in East Asia, after China, South Korea and Japan- and the fifteenth biggest economy in the region on a purchasing power parity (PPP) basis.

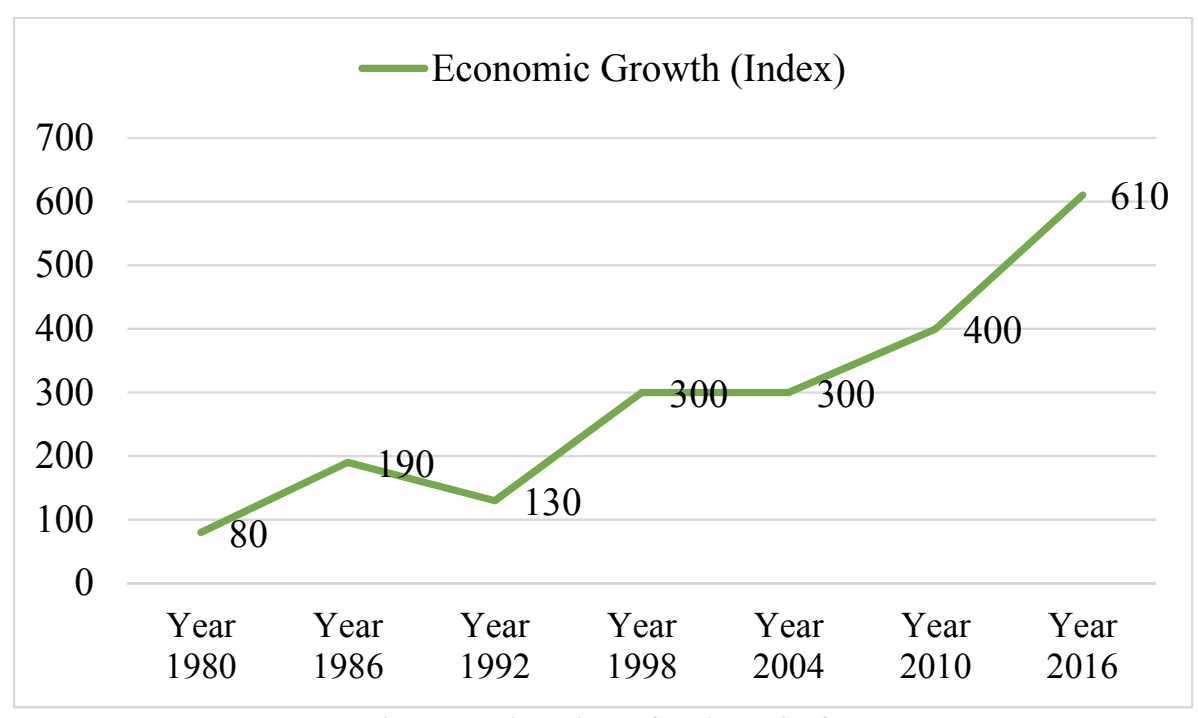

Fig. 1. Economic Growth Index of Indonesia from 1980-2016 Source: IMF Forecast

Foreign direct investment (FDI) and exports are most crucial for every country in the growth of its economy. Both FDI and exports have proved significant for Indonesian economic growth. As exemplified in previous studies, FDI and exports are not only vital in enhancing economic growth (Liu et al., 2002; Sun \& Parikh, 2001) but they also have a vital link with GSC, which is however not mentioned in the previous literature. Different studies have been conducted by researchers but none of these studies examined the role of GSC in economic growth nor did it try to prove that better GSC practices increase the positive effect of FDI and exports on economic growth. It is argued in this study that the Indonesian economy can be improved with the help of GSC practices as well as by the positive effect of FDI and exports. Thus, the purpose of this study is to examine the effect of GSC practices to 
enhance the positive effect of FDI and exports in Indonesia economic growth. The effect of FDI, exports and green supply chain practices are shown in Fig. 2.

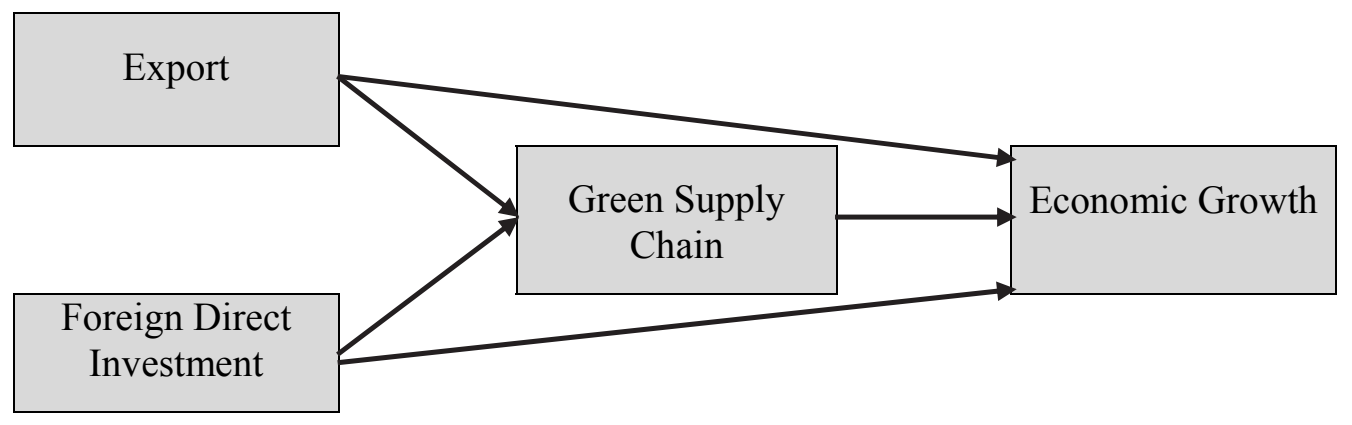

Fig. 2. Conceptual Framework of the study

\section{Review of Literature}

\subsection{Exports, Green Supply Chain and Economic Growth}

During the past few decades, investigations about economic growth and export have remained a critical issue among market analysts. Numerous researchers have endeavoured to explore this relationship (Balassa, 1978; de Pineres \& Ferrantino, 2018; Feder, 1983) which have resulted in three possible situations: positive, negative and no relationship. Besides, another question under consideration deals with the relationship between exports and green supply chain and how it enhances the economic growth of a country. Therefore, the objective of the existing literature is to find out the mutual relationships between exports, GSC, and economic growth.

Green supply chain is described as "carrying products as well as services from suppliers, different manufacturers to customers with the help of information flow, material flow, and transactions of cash flow in the setting of an environment" (Cote et al., 2008; Zhu \& Cote, 2004; Zhu et al., 2010; Ibrahim \& Ali, 2014; Sarwar \& Mubarik, 2014; Okoye, 2014; Wilson et al., 2014; Chidoko, 2014; Ekpung, 2014; Kasasbeh et al., 2018; Hawamdeh, 2018; Yu-Chi \& Lin, 2018). The green supply chain which is environment friendly includes customers, suppliers, purchases, warehouses, packaging, manufacturing, transportation as well as the whole green design in which all stakeholders support the environment making a positive effect on exports and economic growth.

There is a strong relationship between economic growth and supply chain since exports are based on supply chain activities. Particularly green supply chain is more important to economic growth, for being more environmental friendly. A study conducted by Fulconis et al. (2016) provides a new approach for economic growth and highlights a significant association between supply chain and economic growth. According to this study, research in logistics, as well as supply chain, encouraged a new form of economic growth which integrates together societal, ecological and social criteria (Suryanto et al., 2018). Green supply chain management promotes exports and positively influences the economic growth of a country. The modus operandi requires an export exchanging organization to export products to organizations in foreign countries. These export exchanging organizations will provide export documentation, logistics, and transportation, which constitute the supply chain (Lai et al., 2002; Hesse \& Rodrigue, 2004; Fitriandi et al., 2014; Okafor \& Shaibu, 2016; Mokuolu, 2018; Khemili \& Belloumi, 2018; Zhang, 2018; Aremu \& Ediagbonya, 2018; Edeme, 2018). In this process, thus both logistics and transportation related to exports have a direct connection with supply chain management. The green supply chain is also important due to its environmental friendly role (Walton et al., 1998). A study carried out by Rao and Holt (2005) found that green supply chain management had a vital relationship with competitiveness and economic performance. Its findings prove that green supply chain increases 
the economic performance and economic performance of companies and thus has a direct relationship with economic growth.

Studies claim that green supply chain facilitates exports and increases the overall performance of exporting companies and eventually will have a positive effect on economic growth. For instance, Chan et al. (2012) investigated the mediation effect of the supply chain in corporate performance and found that supply chain had increased the overall corporate performance. Another study carried out by Zhu and Sarkis (2007) on the relationship between green supply chain practices and performance and found that there was a significant association between green supply chain and performance (Basheer, 2014; Okon \& Monday, 2017). Therefore, it can be hypothesized that a green supply chain facilitates environmental friendly exports and increase the company's performance and ultimately enhances the economic growth level. The hypotheses formed state thus:

$\mathbf{H}_{1}$ : Exports and green supply chain have a significant positive relationship with each other.

$\mathbf{H}_{2}$ : Exports and economic growth have a significant positive relationship with each other.

\subsection{Foreign Direct Investment, Green Supply Chain and Economic Growth}

Foreign direct investment (FDI) is an investment made to take possession of a business by an entity grounded in another country. A direct control of investment is therefore imminent in all such foreign portfolio investments. It is also understood that an increase in FDI enhances the economic growth of a country (Basheer et al., 2019). To expedite foreign direct investment and enhance the economy of a country, green supply chain is the most crucial factor because better green supply chain activities increases the output of FDI and eventually affects positively the economic growth.

Various studies are available proving the significance of FDI and its crucial role in enhancing the economic growth. Borensztein et al. (1998), for instance, examined the impact of FDI on economic growth in a cross-country study. The authors used time series data on FDI for two decades from 69 different industrial and emerging countries. The results of the study concluded that FDI provides an efficient vehicle for the acceleration of technology and contributes comparatively incessantly to growth as compared with domestic investment. However, the role of political influence in stock returns and enterprise risk management cannot be neglected (Hameed et al., 2017; Maqbool et al., 2018). Moreover, FDI requires supply chain activities which is an evidence that supply chain has a significant relationship with economic growth (Khan et al., 2018). Additionally, as suggested by Khan et al. (2018), if logistics which also contributes to air pollution, is not environmental friendly, the issue can be resolved through green supply chain activities. It is consistent with a few other studies which suggest that green supply chain and logistics practices can control the issue of environmental pollution (Nikbakhsh, 2009; Srivastava, 2007). Zhu and Sarkis (2004) carried out a study on Chinese green supply chain management in the manufacturing sector and argued that China should balance both environmental performance and economic growth in which green supply chain was the most important. Therefore, in line with FDI, the GSC is crucial to enhance the economic growth of Indonesia. The green supply chain has a positive effect on economic growth directly and indirectly by enhancing the positive effect of FDI. Therefore, the following hypotheses are as proposed;

$\mathbf{H}_{3}$ : Foreign direct investment and green supply chain have a significant positive relationship with each other.

$\mathbf{H}_{4}$ : Foreign direct investment and economic growth have a significant positive relationship with each other.

Additionally,

H5: Green supply chain mediates the relationship between exports and economic growth. 
$\mathbf{H}_{6}$ : Green supply chain mediates the relationship between foreign direct investment and economic growth.

\section{Method}

This study uses quantitative research techniques to achieve the objectives. Six hypotheses were proposed with the help of previous studies. These hypotheses were then tested with the help of two statistical software to approach the results. Data was collected from the economists of Indonesia. For this purpose, a questionnaire was developed with the help of previous studies. This questionnaire included close ended questions related to key variables, namely; exports, FDI, green supply chain and economic growth. Responses were restricted to only five options. These five options were; (1) strongly disagree, (2) disagree, (3) Neutral, (4) strongly agree, and (5) agree. The questionnaire included two sections, the first obtained the demographic details of respondents while the second included key items of variables (exports, FDI, green supply chain and economic growth).

After the data collection was over, the data was entered into the excel sheet for further analysis along with missing value analysis however no missing value was found in the data. The outlier was also assessed and was not found. Subsequently, normality test was carried out and the data was found to be normally distributed. All these steps were analysed with the help of SPSS version 21 . In this study, a total number of 70 responses were acknowledged. Therefore, by examining the response rate, Partial Least Square (PLS) was used, which is one of the appropriate tools to analyse the data with small sample size (Henseler et al., 2009; Reinartz et al., 2009). The multicollinearity was examined with the help of VIF value through PLS. The VIF value should be below than 5.0 for each value. Table 1 shows that all the values are below 5.0.

Table 1

Multicollinearity

\begin{tabular}{ll}
\hline Variables & VIF \\
\hline Exports & 3.05 \\
FDI & 2.59 \\
Green Supply Chain & 3.96 \\
Economic Growth & 4.23 \\
\hline
\end{tabular}

\section{Analysis and Results}

In the first part of PLS-SEM, the outer model was analysed with the help of factor loadings, reliability, and validity.

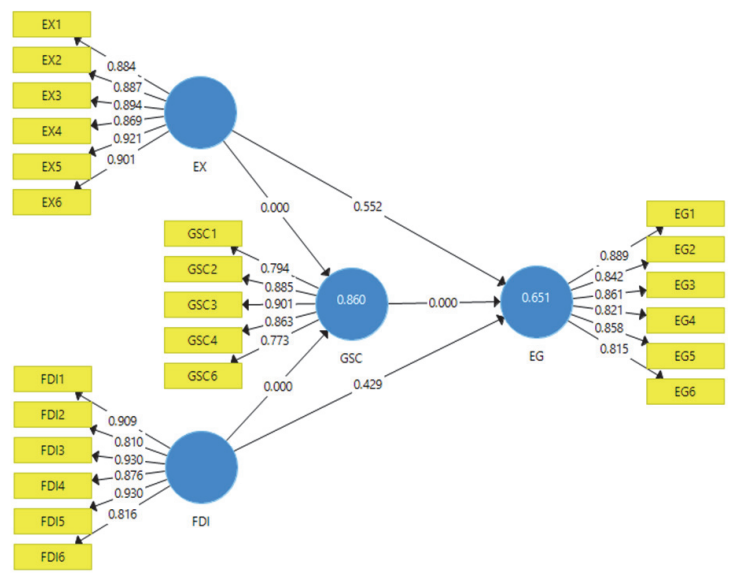

Fig. 3. Outer Model Assessment

To check the convergent validity, average variance extracted (AVE) was analysed. According to various studies F. Hair Jr et al. (2014) and Henseler et al. (2009), the value of factor loading should be 
0.5 or above, reliability should be 0.7 or above and AVE should be above 0.5 . Fig. 3 and Table 2 show the outer model assessment. All the values were meeting the minimum criteria. Table 3 shows the composite reliability, Cronbach Alpha and AVE. Finally, Table 4 shows the discriminant validity.

Table 2

Factor Loadings

\begin{tabular}{|c|c|c|c|c|}
\hline & EG & EX & FDI & GSC \\
\hline EG1 & 0.889 & & & \\
\hline EG2 & 0.842 & & & \\
\hline EG3 & 0.861 & & & \\
\hline EG4 & 0.821 & & & \\
\hline EG5 & 0.858 & & & \\
\hline EG6 & 0.815 & & & \\
\hline EX1 & & 0.884 & & \\
\hline EX2 & & 0.887 & & \\
\hline EX3 & & 0.894 & & \\
\hline EX4 & & 0.869 & & \\
\hline EX5 & & 0.921 & & \\
\hline EX6 & & 0.901 & & \\
\hline FDI1 & & & 0.909 & \\
\hline FDI2 & & & 0.810 & \\
\hline FDI3 & & & 0.930 & \\
\hline FDI4 & & & 0.876 & \\
\hline FDI5 & & & 0.930 & \\
\hline FDI6 & & & 0.816 & \\
\hline GSC1 & & & & 0.794 \\
\hline GSC2 & & & & 0.885 \\
\hline GSC3 & & & & 0.901 \\
\hline GSC4 & & & & 0.863 \\
\hline GSC6 & & & & 0.773 \\
\hline
\end{tabular}

Table 3

Reliability and Validity

\begin{tabular}{lcccc}
\hline & $\boldsymbol{\alpha}$ & rho_A & CR & (AVE) \\
\hline EG & 0.922 & 0.922 & 0.939 & 0.719 \\
EX & 0.949 & 0.951 & 0.959 & 0.798 \\
FDI & 0.941 & 0.947 & 0.954 & 0.774 \\
GSC & 0.899 & 0.9 & 0.925 & 0.714 \\
\hline
\end{tabular}

Table 4

Discriminant Validity

\begin{tabular}{lcccc}
\hline & EG & EX & FDI & GSC \\
\hline EG & 0.848 & & & \\
EX & 0.694 & 0.893 & & \\
FDI & 0.685 & 0.891 & 0.88 & 0.845 \\
\hline
\end{tabular}

\subsection{Structural Model Assessment}

The structural model was assessed to test the hypotheses. First, the direct hypotheses were tested. After that, the mediation effect of the GSC was examined. For the acceptance and rejection of hypotheses, tvalue 1.96 was considered. The relationship having t-value above 1.96 was accepted. However, relationship having t-value below 1.96 was rejected. Direct effect hypotheses are shown in Table 5 and Indirect effect through the green supply chain is shown in Table 6. All the hypotheses have t-value above 1.96 therefore, all the hypotheses are accepted. Fig. 4 shows the structural model process. 


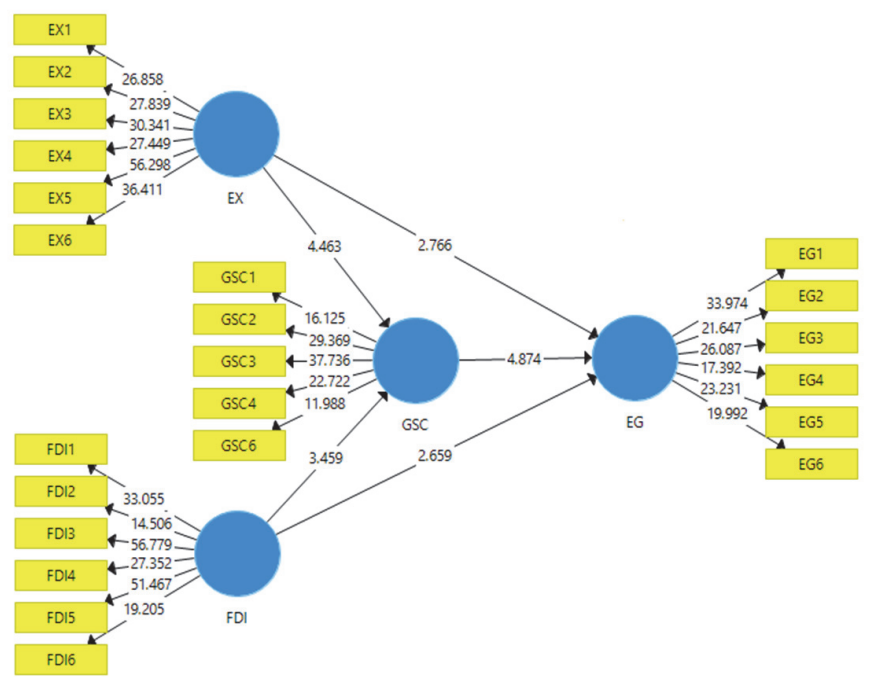

Fig. 4. Inner Model Assessment

Table 5

Direct effect results

\begin{tabular}{lcccccc}
\hline & $(\mathbf{O})$ & $(\mathbf{M})$ & $($ STDEV) & T Statistics & P Values & Decision \\
\hline EX $\rightarrow$ EG & 0.147 & 0.143 & 0.054 & 2.766 & 0.008 & Supported \\
EX $\rightarrow$ GSC & 0.536 & 0.523 & 0.120 & 4.463 & 0.000 & Supported \\
FDI $\rightarrow$ EG & 0.105 & 0.103 & 0.040 & 2.659 & 0.009 & Supported \\
FDI $\rightarrow$ GSC & 0.417 & 0.432 & 0.120 & 3.459 & 0.001 & Supported \\
GSC $\rightarrow$ EG & 1.029 & 1.031 & 0.211 & 4.874 & 0.000 & Supported \\
\hline
\end{tabular}

Table 6

Mediation Effect

\begin{tabular}{lcccccc}
\hline & $(\mathbf{O})$ & $(\mathbf{M})$ & (STDEV) & T Statistics & P Values & Decision \\
\hline $\mathrm{EX} \rightarrow$ GSC $\rightarrow$ EG & 0.552 & 0.539 & 0.172 & 3.205 & 0.001 & Mediation \\
$\mathrm{FDI} \rightarrow$ GSC $\rightarrow$ EG & 0.429 & 0.444 & 0.155 & 2.771 & 0.006 & Mediation \\
\hline
\end{tabular}

Additionally, the R-square value in the current study is 0.642 which shows that all the variables are expected to bring a $64.2 \%$ change in economic growth. This $\mathrm{R}$ square value is substantial according to Chin (1998), which is equal to 0.642 .

\section{Findings}

This study has examined the role of supply chain activities on the economic growth of Indonesia. Contrary to the use of traditional supply chain, this study has adopted green supply chain to find its role in the Indonesian economy. The economists of Indonesia were approached to get responses. This study has formulated six hypotheses to study the relationship between exogenous variables (exports, FDI), endogenous variable (economic growth) and mediating variable (green supply chain). From the analysis of the study, it has found that all constructs have maintained a significant relationship with each other. Moreover, we have found that all variables had a direct relationships with each other which supported all the hypotheses $\left(\mathrm{H}_{1}, \mathrm{H}_{2}, \mathrm{H}_{3}, \mathrm{H}_{4}, \mathrm{H}_{5}, \mathrm{H}_{6}\right)$. First major hypothesis investigated the relationship between the exports and economic growth yields a t-value of 2.766 with beta value of 0.147 , which demonstrates a positive and significant relationship between the two variables. Second major hypothesis of the study tried to find the relationship between FDI and economic growth and it shows a t-value of 2.659 and beta value of 0.105 , which demonstrates a positive and significant relationship. Hence, it proves that, an increase in exports and FDI increases economic growth. However, if there is a decrease in exports and FDI, the economic growth also decreases. The hypothesis between exports and supply chain found t-value of 4.463 and beta value of 0.536 . The hypothesis between FDI and supply chain found t-value 3.459 and beta value 0.417 . Both hypotheses have found a significant relationship and beta value showing that both have a direct relationship. Additionally, the 
hypothesis showing the relationship between supply chain and economic growth also found significant positive with t-value 4.874 and beta value 1.029. Thus, an increase in green supply chain also increases the economic growth. Finally, the mediation hypothesis was also found significant. The mediation effect of green supply chain between exports and economic growth was found significant with t-value 3.205 and beta value 0.552 . The mediation effect of green supply chain between FDI and economic growth was found significant with t-value 2.771 and beta value 0.429 . Thus, it proves that a green supply chain enhances the positive effect of FDI and exports on economic growth.

\section{Conclusion}

While examining the results of this study, it was found that green supply chain practices played an important role on economic growth of Indonesia. Implementation of the green supply chain, rather than traditional supply chain, has maintained a positive impact on FDI and exports of Indonesia. FDI, exports and green supply chain have had an important link with each other. Better green supply chain increases the positive effect of FDI and exports on economic growth. It is found than, an increase in green supply chain increases the FDI and exports. From this study, it is clear that the economic growth of Indonesia can be increased with the help of green supply chain activities. Therefore, the Indonesian government should focus on the green supply chain to expedite exports and FDI. Future research is required to make a comparison between the impact of traditional supply chain activities and green supply chain activities on economic growth. It will provide a better picture to explore how much green supply chain activities are beneficial for the economy. This study is beneficial for economists for making appropriate strategies to promote the economy of the country.

\section{References}

Aremu, J. O., \& Ediagbonya, M. (2018). Trade and Religion in British-Benin Relations, 15531897. Global Journal of Social Sciences Studies, 4(2), 78-90.

Balassa, B. (1978). Exports and economic growth: further evidence. Journal of development Economics, 5(2), 181-189.

Basheer, M. F. (2014). Impact of Corporate Governance on Corporate Cash Holdings: An empirical study of firms in manufacturing industry of Pakistan. International Journal of Innovation and Applied Studies, 7(4), 1371.

Basheer, M., Ahmad, A., \& Hassan, S. (2019). Impact of economic and financial factors on tax revenue: Evidence from the Middle East countries. Accounting, 5(2), 53-60.

Borensztein, E., De Gregorio, J., \& Lee, J. W. (1998). How does foreign direct investment affect economic growth? 1. Journal of international Economics, 45(1), 115-135.

Chan, R. Y., He, H., Chan, H. K., \& Wang, W. Y. (2012). Environmental orientation and corporate performance: The mediation mechanism of green supply chain management and moderating effect of competitive intensity. Industrial Marketing Management, 41(4), 621-630.

Chidoko, C. (2014). Labor and Economic Growth in Zimbabwe. The Economics and Finance Letters, 1(4), 24-29.

Chin, W. W. (1998). The partial least squares approach to structural equation modeling. Modern methods for business research, 295(2), 295-336.

Cote, R. P., Lopez, J., Marche, S., Perron, G. M., \& Wright, R. (2008). Influences, practices and opportunities for environmental supply chain management in Nova Scotia SMEs. Journal of Cleaner Production, 16(15), 1561-1570.

de Pineres, S. A. G., \& Ferrantino, M. J. (2018). Export Dynamics and Economic Growth in Latin America: A Comparative Perspective: A Comparative Perspective. Routledge.

Demir, E., Bektaş, T., \& Laporte, G. (2014). A review of recent research on green road freight transportation. European Journal of Operational Research, 237(3), 775-793.

Edeme, R. K. (2018). Revisiting the economic growth-welfare linkages: Empirical evidence from Nigeria. Asian Themes in Social Sciences Research, 1(1), 28-33. 
Ekpung, E. G. (2014). Public infrastructure spending and economic growth in Nigeria: An Error Correction Mechanism (ECM) approach. Journal of Social Economics Research, 1(7), 129-140.

F. Hair Jr, J., Sarstedt, M., Hopkins, L., \& G. Kuppelwieser, V. (2014). Partial least squares structural equation modeling (PLS-SEM) An emerging tool in business research. European Business Review, 26(2), 106-121.

Feder, G. (1983). On exports and economic growth. Journal of Development Economics, 12(1-2), 5973.

Fitriandi, P., Kakinaka, M., \& Kotani, K. (2014). Foreign direct investment and infrastructure development in Indonesia: Evidence from province level data. Asian Journal of Empirical Research, 4(1), 79-94.

Fulconis, F., Gilles, P., \& Reynaud, E. (2016). Towards a new approach to economic growth-The contributions of research in logistics and supply chain management.

Waseem-Ul-Hameed, F. H., Ali, M., \& Arif, M. (2017). Enterprise risk management (ERM) system: Implementation problem and role of audit effectiveness in Malaysian firms. Asian Journal of Multidisciplinary Studies, 5(11).

Hawamdeh, G. (2018). Countering the crimes of administrative corruption in the international law. International Journal of Asian Social Science, 8(9), 751-769.

Henseler, J., Ringle, C. M., \& Sinkovics, R. R. (2009). The use of partial least squares path modeling in international marketing New challenges to international marketing (pp. 277-319). Emerald Group Publishing Limited.

Hesse, M., \& Rodrigue, J.-P. (2004). The transport geography of logistics and freight distribution. Journal of Transport Geography, 12(3), 171-184.

Hutchins, M. J., \& Sutherland, J. W. (2008). An exploration of measures of social sustainability and their application to supply chain decisions. Journal of Cleaner Production, 16(15), 1688-1698.

Ibrahim, P., \& Ali, M. (2014). Foreign direct investment affluences in Iskandar Malaysia. International Journal of Management and Sustainability, 3(2), 72-83.

Kasasbeh, H. A., Mdanat, M. F., \& Khasawneh, R. (2018). Corruption and FDI Inflows: Evidence from a small developing economy. Asian Economic and Financial Review, 8(8), 1075-1085.

Khan, S. A. R., Dong, Q. L., \& Yu, Z. (2016). Research on the measuring performance of green supply chain management: in the perspective of China. Paper presented at the International Journal of Engineering Research in Africa.

Khan, S. A. R., Qianli, D., SongBo, W., Zaman, K., \& Zhang, Y. (2017). Environmental logistics performance indicators affecting per capita income and sectoral growth: evidence from a panel of selected global ranked logistics countries. Environmental science and pollution research, 24(2), 1518-1531.

Khan, S. A. R., Zhang, Y., Anees, M., Golpîra, H., Lahmar, A., \& Qianli, D. (2018). Green supply chain management, economic growth and environment: A GMM based evidence. Journal of Cleaner Production, 185, 588-599.

Khemili, H., \& Belloumi, M. (2018). Cointegration relationship between growth, inequality and poverty In Tunisia. International Journal of Applied Economics, Finance and Accounting, 2(1), 818.

Lai, K.-h., Ngai, E., \& Cheng, T. (2002). Measures for evaluating supply chain performance in transport logistics. Transportation Research Part E: Logistics and Transportation Review, 38(6), 439-456.

Liu, X., Burridge, P., \& Sinclair, P. J. (2002). Relationships between economic growth, foreign direct investment and trade: evidence from China. Applied Economics, 34(11), 1433-1440.

Maqbool, N., Hameed, W., \& Habib, M. (2018). Impact of political influences on stock returns. International Journal of Multidisciplinary Scientific Publication (IJMSP), 1(1).

Martel, A., \& Klibi, W. (2016). Designing value-creating supply chain networks. Springer.

Mokuolu, J. O. (2018). Assessment of the development and growth of Nigerian economy as a function of FDI flows. Journal of Accounting, Business and Finance Research, 2(2), 91-97.

Nikbakhsh, E. (2009). Green supply chain management Supply chain and logistics in national, international and governmental environment (pp. 195-220). Springer. 
Okafor, C., \& Shaibu, I. (2016). Modelling economic growth function in Nigeria: An ARDL approach. Asian Journal of Economics and Empirical Research, 3(1), 84-93.

Okon, E. O., \& Monday, O. I. (2017). Empirical and evidence-based investigation: External debt, poverty and economic growth nexus. International Journal of Applied Economics, Finance and Accounting, 1(1), 37-47.

Okoye, J. C. (2014). Anti-corruption crusade in Nigeria: More words than deeds. International Journal of Public Policy and Administration Research, 1(2), 47-63.

Rao, P., \& Holt, D. (2005). Do green supply chains lead to competitiveness and economic performance? International Journal of Operations \& Production Management, 25(9), 898-916.

Reinartz, W., Haenlein, M., \& Henseler, J. (2009). An empirical comparison of the efficacy of covariance-based and variance-based SEM. International Journal of research in Marketing, 26(4), 332-344.

Sarwar, N., \& Mubarik, M. S. (2014). Foreign Direct Investment (FDI) and Employment: A Case of province of Punjab, Pakistan. The Economics and Finance Letters, 1(4), 59-65.

Srivastava, S. K. (2007). Green supply-chain management: a state-of-the-art literature review. International Journal of Management Reviews, 9(1), 53-80.

Sun, H., \& Parikh, A. (2001). Exports, inward foreign direct investment (FDI) and regional economic growth in China. Regional Studies, 35(3), 187-196.

Suryanto, T., Haseeb, M., \& Hartani, N. H. (2018). The correlates of developing green supply chain management practices: Firms level analysis in Malaysia. International Journal of Supply Chain Management, 7(5), 316.

Walton, S. V., Handfield, R. B., \& Melnyk, S. A. (1998). The green supply chain: integrating suppliers into environmental management processes. International Journal of Purchasing and Materials Management, 34(1), 2-11.

Wilson, A., David, U., Mary, O., \& Beatrice, E. (2014). How telecommunication development aids economic growth: Evidence from Itu Ict Development Index (IDI) top five countries for African region. International Journal of Business, Economics and Management, 1(2), 16-28.

Yu-Chi, S., \& Lin, H. P. (2018). Causality relationship between tourism, foreign direct investment and economic growth in Taiwan. Asian Journal of Economic Modelling, 6(3), 287-293.

Zhang, W. B. (2018). Endogenous economic growth with education subsidies. International Journal of Emerging Trends in Social Sciences, 2(1), 10-16.

Zhu, Q., \& Cote, R. P. (2004). Integrating green supply chain management into an embryonic ecoindustrial development: a case study of the Guitang Group. Journal of Cleaner Production, 12(810), 1025-1035.

Zhu, Q., \& Sarkis, J. (2004). Relationships between operational practices and performance among early adopters of green supply chain management practices in Chinese manufacturing enterprises. Journal of operations management, 22(3), 265-289.

Zhu, Q., \& Sarkis, J. (2007). The moderating effects of institutional pressures on emergent green supply chain practices and performance. International Journal of Production Research, 45(18-19), 43334355.

Zhu, Q., Geng, Y., \& Lai, K.-h. (2010). Circular economy practices among Chinese manufacturers varying in environmental-oriented supply chain cooperation and the performance implications. Journal of Environmental Management, 91(6), 1324-1331.

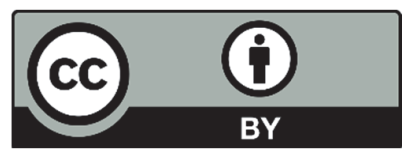

(C) 2019 by the authors; licensee Growing Science, Canada. This is an open access article distributed under the terms and conditions of the Creative Commons Attribution (CC-BY) license (http://creativecommons.org/licenses/by/4.0/). 